\title{
散乱法を用いた環状高分子の溶液中・バルク中の物性評価
}

高野 敦志

(名古屋大学 工学研究科)

\section{Solution and Bulk Properties of Ring Polymers Investigated by Scattering Methods}

Atsushi Takano

Department of Applied Chemistry, Nagoya University

\section{0}

\begin{abstract}
Although numerous works on physical properties of ring polymers were made for three decades, most of ring polymer samples used so far were not pure enough. Recently new HPLC technique with high resolution has provided rigorous characterization of rings. In this article, recent developments in solution and bulk properties of well-characterized ring polymers with high purity are described.

Keywords: ring polymer, radius of gyration, hydrodynamic radius, second virial coefficient
\end{abstract}

1. はじめに

環状高分子は末端のない一次構造を持つために 線状高分子と様々な物性が異なると考えられてい る. 例えば末端の欠如のために環状高分子は線状 高分子のような絡み合いを生じにくくなることが 予想され，分子の拡がり（サイズ）や運動性など は大きな影響を受けると考えられる。これまで数 多くの実験的な報告がなされてきたが，既存の環 状高分子試料は厳密な分析方法がなかったため, 環状分子の含有率を定量的に調べることなく，物 性評価に供されてきた。しかし、最近、臨界条件 液体クロマトグラフィー（LCCC）という新しい HPLC(High performance liquid chromatography)技術 の開発によって環状高分子と線状高分子の分離が 可能となり，これまで使用されてきた環状高分子 試料には線状高分子がかなり含まれている（10\% 以上）ことが明らかにされた [1]。この指摘はこれ まで提出された物性データに対する信頼性に疑問 を投げかけると同時に，環状高分子物性の本質解 明に対して線状分子の含まれない高純度環状高分 子試料による測定が必要不可欠であることを認識 させることになった。こうした背景のもと，筆者 らの研究グループでは，アニオン重合を用いた精 密合成技術と分解能の高い HPLC 技術を駆使する ことにより純度の高い環状高分子試料の調製に取 り組み，特に環状高分子の拡がりをはじめとする 溶液，ならびにバルク中における物性評価を行っ ている．高分子の回転半径の測定に際しては，い くつかの散乱法を併用することが広い qレンジを カバーした測定に有効である。光散乱法のみでも 広い q レンジをカバーしているが，比較的小さい qレンジ領域や，特にバルク中での回転半径の測 定には中性子散乱が必要不可欠である. 本稿では, 主に中性子散乱と光散乱の 2 つの散乱技術を利用
して得られた環状高分子の拡がりの分子量依存性 や相互作用係数（第 2 ビリアル係数）など最新の 実験結果と今後の展望などについて解説する.

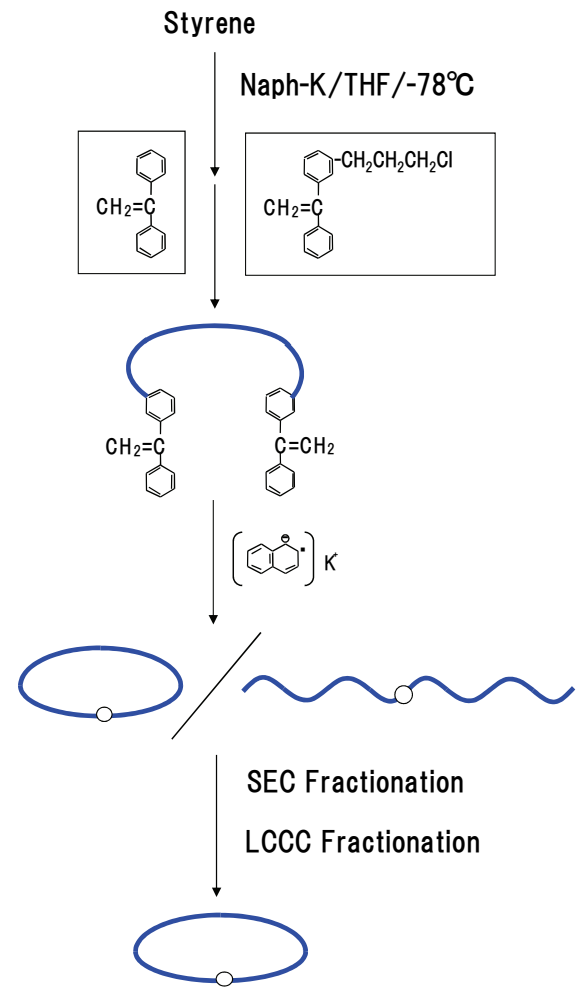

Fig.1 Synthetic scheme of ring polystyrene. 
2. 環状高分子の精密合成

Fig.1 に示すようなスキームに従って末端に 1,1-ジフェニルエチレン（DPE）型ビニル基を有 するテレケリックポリスチレンをプレポリマーと して希薄条件下，ナフタレンカリウムを反応させ ることにより末端連結反応を行い，さらに液液分 別，あるいはSEC 分取により，環状高分子試料の 単離を行った。最終的な収率は分子量 5 万，およ び 60 万のものでそれぞれ約 35\%，および 3\%を実 現した[2].

合成された試料中に含まれる環状分子の定量的 純度測定を行うため LCCC 分析を行った。 Fig.2 に SEC と LCCC による測定例の比較を示す. 例え ば、SEC 測定では分子量 $\mathrm{M}_{\mathrm{w}}$ の等しい線状高分子 と環状高分子のピークは重なっているが，線状ポ リスチレンの LCCC 条件を用いて測定を行うと含 有するす心゙て線状分子は分子量依存性がなくなり 同じ溶出時間に溶出するのに対し，環状分子は異 なる溶出時間に現れる. LCCC 条件における試料 測定の結果，環状高分子と線状高分子が完全に心゙ 一スライン分離されることが分かる。このような LCCC 測定によるピーク面積比較よりいずれの環 状試料とも少なくとも $95 \%$ 以上の環状分子純度 を有することが確認された[2].これらの合成，お よび分析を通して分子量分布が狭く, かつ環状高

a

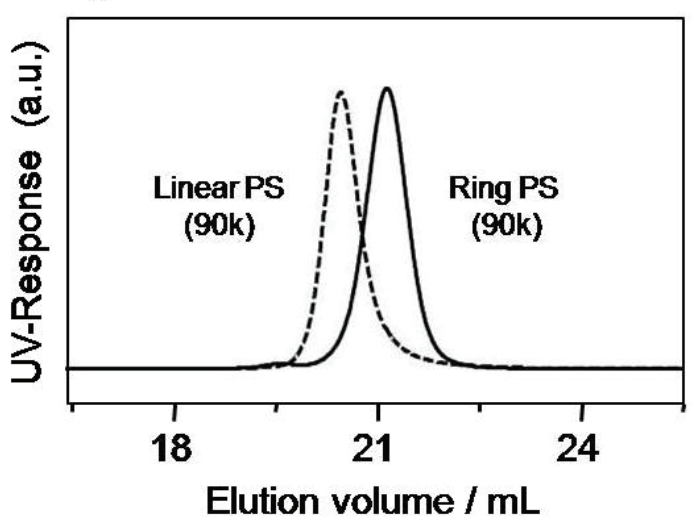

b

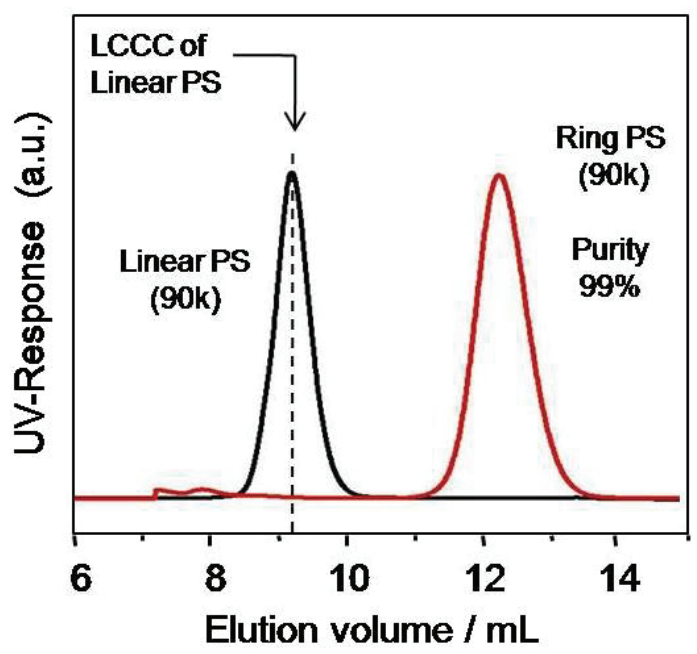

Fig.2 Comparison of separation of linear/ring polystyrenes by (a) SEC and (b) LCCC.
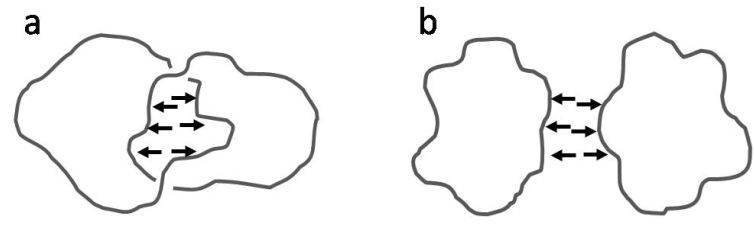

Fig.3 Topological interaction between two ring polymers. (a) attractive interaction, (b) repulsive interaction

分子純度の高い $16 \mathrm{k} \leqq \mathrm{M}_{\mathrm{w}} \leqq 600 \mathrm{k}$ の 6 種類の環状ポ リスチレン $\mathrm{h}_{8}$ 、ならびに $16 \mathrm{k} \leqq \mathrm{M}_{\mathrm{w}} \leqq 120 \mathrm{k}$ の 3 種 類の環状ポリスチレンー $\mathrm{d}_{8}$ を得た.

3. 環状ポリスチレンの第 2 ビリアル係数

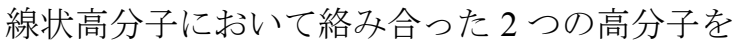
引き離そうとする場合には引力が働くのに対し， 絡み合っていない 2 つ分子を近づける場合には 逆に斥力が働く.このような力は「トポロジーカ」, あるいは「トポロジー的相互作用」と呼ばれる. 線状高分子の場合にはこうした引力と叐力は生 成・消滅が可能なため平均としてはゼロである.

一方，環状高分子 2 分子間の場合，絡み合いに伴 う引力, 斥力は Fig.3 のように一旦生成したなら ば高分子が切断されない限り永久に保たれること になり，実効的に働くはずである．実在の環状高 分子は希薄条件で環化反応が行われ, 合成されて いることから，基本的に Fig.3(a)のようなカテナ ン型高分子はほとんど存在しないと考えられる. そのため、Fig.3 (b)のトポロジー的斥力が優勢に 働き, 線状高分子に比べて溶解性が高くなること が予想される [3-6]。（すなわち線状高分子の $\theta$ 温度 $\left(\mathrm{A}_{2}=0\right.$ の温度）において, 環状高分子の第 2 ビリ アル係数 $\mathrm{A}_{2}$ は正の值を取る.)

著者らはシクロヘキサン中, 4 種類の環状ポリ スチレン試料の静的光散乱測定から $\mathrm{A}_{2}$ の温度依 存性を調べた（Fig.4）。その結果, 線状高分子の $\theta$ 温度 $\left(\mathrm{T}_{\theta}=34.5^{\circ} \mathrm{C}\right)$ における環状高分子の $\mathrm{A}_{2}$ は いずれも正の值を示し，さらに $\mathrm{A}_{2}=0$ となる温度 $\mathrm{T}_{\theta}$ は $27.7^{\circ} \mathrm{C}$ で, 線状物の值に比べ, 約 6.8 度も低 いことが示された。このように環状高分子の $\theta$ 温

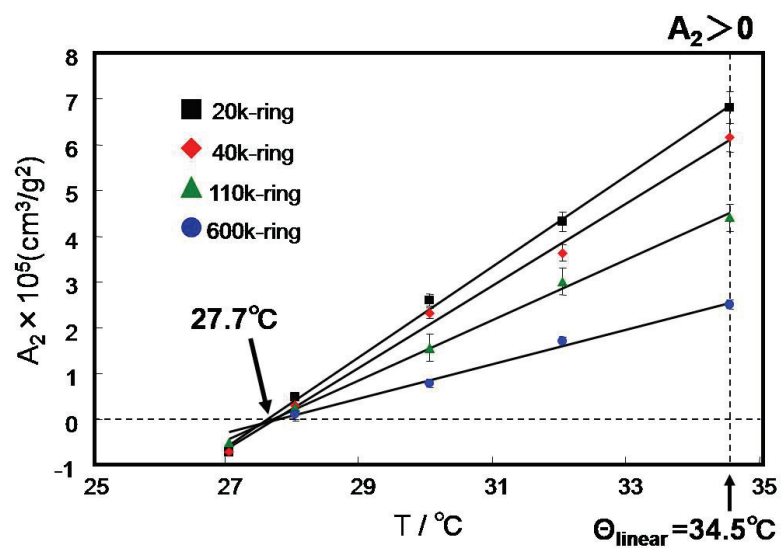

Fig.4 Temperature dependence of $\mathrm{A}_{2}$ for ring polystyrenes in cyclohexane. 
度の低下は「トポロジカル相互作用」を考慮した 理論予測と一致している [7].

4. 環状高分子の溶液中の回転半径の分子量依存 性

Zimm らはガウス鎖近似により環状高分子の非 摂動状態における平均 2 乗回転半径を $\mathrm{R}_{\mathrm{g}}{ }^{2}=\mathrm{nb}^{2} / 12$ と計算しており，これは同分子量の線状高分子の $\mathrm{R}_{\mathrm{g}}{ }^{2}$ に対する比が

$$
\mathrm{g}_{\mathrm{s}} \equiv \mathrm{R}_{\mathrm{g}}{ }^{2}(\text { ring }) / \mathrm{R}_{\mathrm{g}}{ }^{2}(\text { linear })=1 / 2
$$

であることを示している $[8]$. (ここでn は重合度， b は結合長を示す. ) これまで $\mathrm{g}_{\mathrm{s}}$ こついては環状ポ リスチレン試料で概ね 0.5 に近い值が得られてい るほか[9], ポリジメチルシロキサン試料でも 0.53 という值が得られており，理論に近い值が報告さ れている $[10]$ 。しかし，最近，筆者らは上述の高 純度環状ポリスチレン $\left(16 \mathrm{k} \leqq \mathrm{M}_{\mathrm{w}} \leqq 570 \mathrm{k}\right)$ の回 転半径測定の結果, $\mathrm{g}_{\mathrm{s}}=0.62$ という理論に比べて かなり大きい值を報告しており，トポロジカルな 相互作用による膨潤効果を受けている可能性を指 摘している $[11]$.

また，Zimm らの理論は環状高分子の回転半径 の分子量依存性は線状鎖のそれと等しいことも予 想している. Hadziioannou らは Rempp らの合成し た環状高分子試料 $\left(10 \mathrm{k} \leqq \mathrm{M}_{\mathrm{w}} \leqq 198 \mathrm{k}\right)$ を利用し てシクロヘキサン中， $34.5^{\circ} \mathrm{C}$ で回転半径の分子量 依存性を求め, それが線状鎖の分子量依存性 (0.5) とほぼ等しいことを報告している [9]。しかし，前 節の第 2 ビリアル係数の異常性からも予想できる ように, 線状高分子の $\mathrm{A}_{2}=0$ の温度における環状 高分子の $\mathrm{A}_{2}$ は正であり, 分子量依存性自体も線状 高分子の依存性と同じにならない可能性がある. 筆者らは高純度環状ポリスチレン ( $16 \mathrm{k}$ $\leqq \mathrm{M}_{\mathrm{w}} \leqq 570 \mathrm{k} ）$ を用いてシクロヘキサン中, $34.5^{\circ} \mathrm{C}$ で回転半径の分子量依存性を求めた結果，分子量 依存性の指数が 0.52 程度であることがわかった

(Fig.5)．線状高分子と比べると分子量範囲も狭 く，データ点数も少ないことから，この值の信憑 性は十分とは言えないが，理論值の 0.5 よりやや 大きい值が得られていることは，環状高分子のト

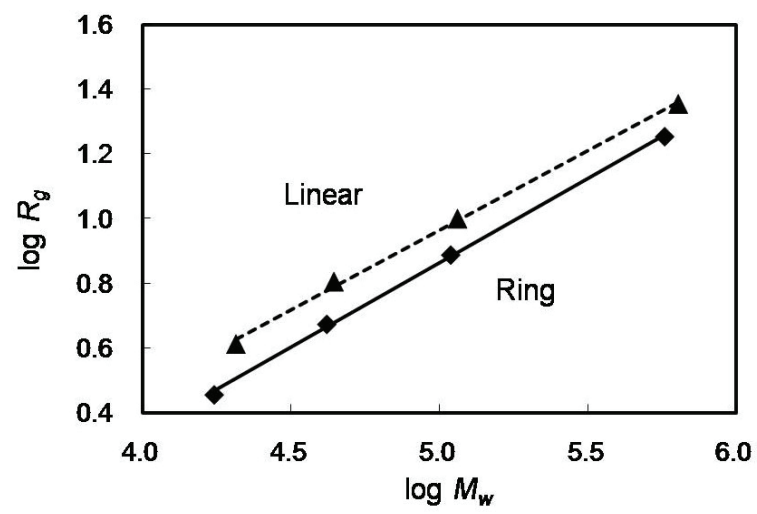

Fig.5 Molecular weight dependence of radii of gyration of linear- and ring polystyrenes in cyclohexane.
ポロジカルな相互作用が回転半径の分子量依存性 に影響を与えている可能性を示唆している $[11]$.

5. 環状高分子のバルク中の回転半径の分子量依 存性

一方，バルク（溶融体）中の回転半径の分子量 依存性についても理論，ならびに実験が行われ，

議論がなされている. 溶融中における線状高分子 の回転半径が非摂動状態にあり，分子量依存性の 指数が 0.5 になることはよく知られている. その 一方で，溶融体中の環状高分子鎖は周りの環状鎖 からトポロジカルな相互作用を受け，この指数が $0.5 よ り$ 小さなることが理論的, あるいは計算機 シミュレーションにより予想されている.例えば, Cates らにより，1/2〜1/3[12], Brown らにより $0.42[13]$, Muller らにより $0.39[14]$, さらに最近 では Suzuki らにより 1/3[15]という值などが予想 されており,いずれの值とも 0.5 に比べて小さい. 実験的には, Arrighi らが重水素化, ならびに軽水 素化ポリジメチルシロキサンを用いた中性子散乱 実験により，指数を 0.42 と報告している $[16]$.ま た, 最近, 筆者らも重水素化, ならびに軽水素化 ポリスチレンを用いた中性子散乱実験により，指 数 0.34 を求めているが，いずれのデータとも分子 量範囲が狭く, 分子量依存性の指数が正確に求ま っているかどうかは疑わしい[11]（Fig.6）.今後, より広い分子量範囲の試料を調製してさらなる精 度の高い実験が望まれる。

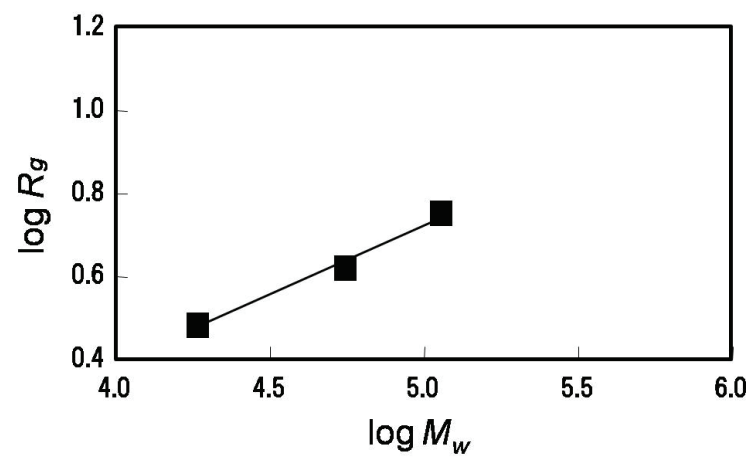

Fig.6 Molecular weight dependence of radii of gyration of ring polystyrenes in bulk.

\section{7. 今後の展望}

環状高分子の物性研究ではこれまで多くの実験 報告があり，既に決着がついたものと思われてい たが, 前述のとおり, 高分解能 HPLCにより単離 された高純度環状試料の利用による物性測定によ り，新しい展開がなされつつある。特に、最近の 環状高分子の粘弾性に関する報告では, 高純度環 状高分子の粘弾性スペクトルには線状高分子に特 徵的に現れるゴム状平坦領域（プラトー）がほと んど現れず，絡み合いが生じにくいことが報告さ れている $[17,18]$.さらに驚くべきことに，この高 純度環状高分子の中に数パーセント程度の同分子 
量線状高分子を添加するだけで，プラトーが回復 し，絡み合いが生成してくることも報告されてい る $[17,18]$.この線状分子のブレンドの効果は添加 された線状鎖がマトリックスである環状鎖を「串 刺し」にして効果的に絡み合いを生成していると 考えられる.このような描像を証明する一つの方 法としては，環状高分子に線状分子を添加してい った際の環状分子の回転半径が「串刺し効果」に より膨らむのかどうかを中性子散乱実験で追跡す ることが有効であろう。

また，分離技術の進歩とともに，最近の高分子 精密合成技術の進歩により，基本的な環状高分子 ばかりでなく,Fig.7に示すような絡み目や結び目 を有するトポロジカル異性体，すなわちカテナン 型環状高分子やノット型環状高分子などの合成も 可能になりつつある $[19,20]$. これらのキャラクタ リゼーションに対しても中性子散乱は大きな貢献 を果たすものと考えられる.
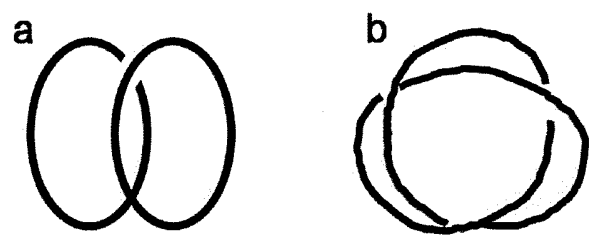

Fig.7 Topological isomers of ring polymers. (a) catenated ring polymer, (b) knotted ring polymer.

以上，散乱法を利用した環状高分子の物性研究 について述べさせていただいたが，今後，環状高 分子を利用した研究がさらに発展し, 高分子科学 の本質を解明するような研究成果が生まれてくる ことを心から期待する。

\section{参考文献}

[1] H. C. Lee, H. Lee, T. Chang, and J. Loovers, Macromolecules, 33, 8119 (2000)

[2] D. Cho, K. Masuoka, K .Kouguchi, T. Asari, A. Takano, and Y. Matsushita, Polymer J. 37, 506 (2005)

[3] K. Iwata, Macromolecules, 18, 115(1985)

[4] F. Tanaka, J.Chem.Phys., 87, 4201 (1987)

[5] K. Iwata, Macromolecules, 22, 3702 (1989)

[6] T. Deguchi and K. Tsurusaki, Proceeding of Lectures at Knots96, 95, (1997)

[7] A. Takano, Y. Kushida, Y. Ohta, K. Masuoka, and Y. Matsushita, Polymer, 50, 1300 (2009)

[8] B. H. Zimm, W. H. Stockmayer, J.Chem.Phys. 17, 1301 (1949)

[9] G. Hadziioannou, P. M. Cotts, G. ten Brinke, C. C. Han, P. Luts, C. Strazielle, P. Rempp, A. J. Kovacs, Macromolecules, 20, 493 (1987)

[10] C. J. C. Edwards, R. F. T. Stepto, "Cyclic Polymers", J. A. Semlyen, Ed., Elsevier, London, (1986) Chapter4

[11] Y. Ohta, A. Takano, K. Masuoka and Y. Matsushita, manuscript in preparation
[12] M. E. Cates, J. M. Deutsch, J.Physique, 47, 2121 (1986)

[13] S. Brown and G. Szamel, J. Chem. Phys., 108, 4705 (1998)

[14] M. Muller, J. P. Witter and M. E. Cates, Phys.Rev.E, 53, 5063 (1996)

[15] J. Suzuki, A. Takano and Y. Matsushita, J.Chem.Phys., 129, 034903 (2008)

[16] V. Arrighi, S. Gagliardi, A. C. Dagger, J. A. Semlyen, J. S. Higgins, M. J. Shenton, Macromolecules, 37, 8057 (2004)

[17] M. Kapnitos, M. Lang, D. Vlassopoulos, W. Pyckhout-Hintzen, D. Richter, D. Cho, T. Chang and M. Rubinstein, Nat. Mat. 7, 997( 2008)

[18] A. Takano, K.Matsubara, Y. Matsushita, Y. Takahashi and $\mathrm{H}$. Watanabe, manuscript in preparation

[19] Y. Ohta, Y. Kushida, D. Kawaguchi and Y. Matsushita, A. Takano, Macromolecules 41, 3957 (2008)

[20] Y. Ohta, Y. Kushida, Y. Matsushita and A. Takano, Polymer 50, 1297 (2009) 